\title{
POLITIK PENDIDIKAN ISLAM DALAM KONFIGURASI SISTEM PENDIDIKAN DI INDONESIA
}

\author{
Hamlan \\ STAIN Datokarama Palu, Jl. Diponegoro No. 23 Palu \\ e-mail: hamlan_andi@yahoo.co.id
}

\begin{abstract}
Abstrak. Pendidikan Islam di Indonesia telah mengalami perubahan dan perkembangan dalam peta politik pendidikan nasional. Perubahan dan perkembangan pendidikan Islam tersebut dipengaruhi oleh kepentingan ideologi politik dan kepentingan lainnya dalam pengambilan kebijakan negara. Hal ini tercermin dengan lahirnya berbagai kebijakan negara tentang pendidikan nasional yang memposisikan pendidikan Islam dalam sistem pendidikan Nasional sejak masa pemerintahan Soekarno sampai pada masa pemerintahan Orde Reformasi.

Abstract. Islamic education in Indonesia has undergone changes and developments in the political map of national education. Changes and the development of Islamic education is influenced by the interests of political ideology and other interests in state policy-making. This is reflected by the establishment of various national education policy of the state of the position of Islamic education in the national education system since the time of Sukarno until the reign of Reform Order.
\end{abstract}

Kata kunci: pendidikan Islam, politik, orde Baru, orde Reformasi 


\section{PENDAHULUAN}

Dalam konteks pendidikan Islam Indonesia, setelah proklamasi kemerdekaannya, pemerintah membentuk Departemen Agama yang memegang kewenangan utama dalam penyelenggaraan bidang agama. Salah satu bentuk kewenangan tersebut adalah terkait dengan pengembangan institusi pendidikan Islam. Namun, kewenangan Departemen Agama yang terkait dengan pendidikan Islam telah melahirkan sejumlah kebijakan yang berimplikasi pada kultural dan politis.

Secara kultural, pendidikan Islam dalam bentuk pesantren di Jawa, maunasah di Aceh, Surau di Minangkabau dan madrasah sebagai lembaga pendidikan Islam yang telah mengalami proses transformasi keilmuan dan kelembagaan adalah lembaga pendidikan Islam yang telah menyejarah. Usia pendidikan Islam lebih tua dari kemerdekaan RI sehingga tidak dapat dipisahkan dari kultur bangsa ini.

Secara politis, jauh sebelum kemerdekaan RI, pemerintah kolonial Belanda dan Jepang melakukan kontrol terhadap penyelenggaraan pendidikan Islam yang notabene diselenggarakan oleh umat Islam. Kontrol tersebut dimotivasi oleh pertimbangan politis bahwa umat Islam di Nusantara adalah komunitas yang mayoritas, sehingga mesti diakomodasi kepentingan politik dan edukasinya guna mengukuhkan legitimasi kekuasaan.

Setelah Indonesia merdeka pemerintah menetapkan sejumlah kebijakan politik pendidikan yang secara fungsional umat Islam mendapatkan manfaat atas kebijakan politik pendidikan pemerintah, terutama bagi pengembangan dan peningkatan mutu pendidikan Islam.

Atas dasar ini lahir berbagai kebijakan negara tentang sistem pendidikan nasional yang memuat tentang relasi antara pendidikan Islam dalam sistem pendidikan nasional, di antaranya lahir Undang-Undang Nomor 4 tahun 1950 Jo. Nomor 12 tahun 
1954 tentang Pendidikan dan Pengajaran di Sekolah, UndangUndang Nomor 2 tahun 1989 tantang Sistem Pendidikan Nasional dan Undang-Undang Nomor 20 tahun 2003 tantang Sistem Pendidikan Nasional. Dalam Undang-undang tersebut posisi pendidikan Islam mengalami perubahan sesuai dengan pengaruh kepentingan oleh pemangku kepentingan dalam pengambilan keputusan kebijakan negara tentang sistem pendidikan nasional.

\section{LANDASAN TEORI}

Tulisan ini menggunakan pendekatan-teori politik yaitu valuational yang bersifat idiologi politik. Teori ini dikembangkan oleh Thomas P. Jenkin. ${ }^{1}$ Penulis menggunakan teori valuational yang bersifat ideologi politik karena kebijakan-kebijakan negara yang berkenaan dengan pendidikan selalu dikaitkan dengan moral dan nilai terhadap produk kebijakan negara dalam bidang pendidikan sesuai dengan corak dan aliran ideologi yang dominan dalam mengambil kebijakan negara.

Apabila aliran ideologi yang nasionalis dominan dalam mengambil kebijakan negara, maka corak dan substansi dari kebijakan itu akan relevan dan berpengaruh terhadap corak ideologi yang dianutnya. Demikian pula, jika aliran ideologi politik yang religius menjadi faktor yang dominan dalam mengambil kebijakan negara, maka corak dan substansi dari kebijakan itu pun akan sesuai dan relevan dengan aliran ideologi yang bercorak religius.

Merujuk atas teori politik tersebut menunjukkan hubungan antara pendidikan dan politik adalah seperti dua sisi mata uang yang antara satu dengan lainnya saling terkait dan tidak dapat dipisahkan. Antara pendidikan dan politik secara fungsional saling membutuhkan dan menunjang dalam rangka peningkatan, pertumbuhan dan perkembangan pendidikan Islam di Indonesia.

\footnotetext{
${ }^{1}$ Thomas P. Jenkin, The Study of Political Theory, (New York: Random House Inc., 1967), h. 1-5.
} 


\section{KEBIJAKAN POLITIK PENDIDIKAN ISLAM DALAM SISTEM PENDIDIKAN NASIONAL}

Di masa awal berdirinnya negara 1945-1966, pertentangan antara kepentingan politik dan aliran ideologi nasionalis sekuler dan nasionalis Islam acap kali terjadi dalam memutuskan kebijakan. Keadaan yang demikian berimplikasi terhadap kebijakan pemerintah yang belum mencerminkan pendidikan Islam sebagai lembaga pendidikan yang terintegrasi ke dalam sistem pendidikan nasional. Pendidikan Islam sepenuhnya di bawah tanggung jawab Departemen Agama yang dibentuk untuk membidangi masalah-masalah keagamaan.

Pendirian Departemen Agama dilatari oleh kebijakan politik umat Islam setelah Indonesia merdeka. Pemerintah Republik Indonesia baru dibentuk oleh koalisi Muslim dan beberapa partai nasionalis, antara lain Masyumi, Nahdhatul Ulama, PNI, dan PKI. Meskipun selama tahun-tahun peperangan, pihak Muslim menjadi kekuatan organisasi politik yang besar, namun kemudian kekuatan mereka terkalahkan oleh kekuasaan Partai Nasionalis Indonesia yang bercorak nasionalis sekuler. ${ }^{2}$

Perdebatan-perdebatan antara kelompok Muslim yang beraliran politik dan ideologi yang agamis (Islam) berpandangan bahwa agama dan negara tidak dapat dipisahkan dan menuntut Islam dijadikan sebagai dasar negara apabila Indonesia merdeka, sedangkan golongan nasional dalam aliran politik dengan ideologi sekulernya menghendaki Pancasila sebagai dasar negara.

Ditinjau dari perspektif kehidupan kenegaraan, muara dari keinginan dan upaya pemikir dan aktivis politik Islam adalah menempatkan posisi Islam secara pas dalam kehidupan kenegaraan, yaitu dengan menjadikan Islam sebagai dasar negara. Muhammad Natsir selaku tokoh Masyumi merupakan salah seorang artikulator penting dari gagasan ini. Bahkan, sebelum

${ }^{2}$ Musyrifah Sunanto, Sejarah Peradaban Islam Indonesia, (Cet. I; Jakarta: RajaGrafindo Persada, 2005), h. 61 
Indonesia merdeka, pada tahun 1930-an, Natsir telah terlibat dalam perdebatan dengan Soekarno tentang hal krusial tersebut. ${ }^{3}$

Gagasan menjadikan Islam sebagai dasar negara kembali mewacana dalam sidang Badan Pelaksana Usaha Persiapan Kemerdekaan Indonesia (BPUPKI). Perdebatan itu berakhir tanggal 22 Juni 1945 setelah adanya kompromi dan kesepakatan, yaitu kelompok Islam agamis, nasionalis dan kelompok nasionalis sekuler berkaitan dengan dijadikannya Piagam Jakarta sebagai Mukadimah UUD 1945. Namun, pada tanggal 18 Agustus 1945, kesepakatan itu berubah dengan penerimaan rumusan Pancasila tanpa disertai Piagam Jakarta. Perubahan itu diterima oleh kelompok Islam yang berideologi agamis, karena situasi saat itu mengharuskan adanya prioritas pilihan. ${ }^{4}$

Perubahan atas dasar negara tersebut didasarkan pada pertimbangan politis untuk persatuan dan kesatuan bangsa. Namun, proses perubahannya dalam sidang PPKI tanggal 18 Agustus 1945 berlangsung dalam waktu yang sangat singkat. Perubahan dasar negara itu menimbulkan pertanyaan umat Islam dan perasaan tidak puas, karena Piagam Jakarta telah disepakati sebelumnya yang mencantumkan syariat Islam sebagai dasar negara sebagaimana yang tercantum dalam Piagam Jakarta.

Dalam perkembangan selanjutnya, untuk meredam keinginan umat Islam setelah Indonesia merdeka, pemerintah menyediakan pembentukan Departemen Agama pada tanggal 3 Januari 1946 sebagai konsensi bagi umat beragama khususnya

\footnotetext{
${ }^{4}$ Kalangan nasionalis Islam menilai bahwa bukanlah saat yang tepat untuk memprotes perubahan itu, pada saat bangsa Indonesia dituntut untuk mempertahankan kemerdekaan. Yang menjadi pertimbangan lain adalah Pidato Presiden Soekarno tanggal 1 Juni 1945 yang kemudian dikenal sebagai "hari lahir Pancasila" serta pernyataan janjinya pada tanggal 18 Agustus 1945 yang menekankan bahwa UUD 1945 bersifat sementara. Lihat Firdaus Syam, Amin Rais dan Yusril Ihza Mahendra di Pentas Indonesia Modern, (Cet. I; Jakarta: Khairul Bayan, 2003), h. 48.
} 2005), h. 43.

${ }^{3}$ Bahtiar Effendy, Jalan Tengah Politik Islam, (Cet. I; Jakarta: Ushul Press, 
bagi umat Islam. Departemen ini dibentuk untuk melindungi kebebasan beragama, menjaga keserasian hubungan antara kemunitas agama yang berbeda, dan yang utama adalah untuk menangani masalah keagamaan Muslim, seperti pendidikan Islam, perkawinan, haji, dakwah, dan mengelola peradilan agama. $^{5}$

Dalam kaitan ini, B.J. Boland mengemukakan bahwa berdirinya Departemen Agama membawa makna positif bagi kepentingan umat Islam. Makna positif ini meliputi hal-hal sebagai berikut: 1) kementerian ini menawarkan kemungkinan bagi agama, khususnya agama Islam, untuk berperan seefektif mungkin dalam negara dan masyarakat; 2) dalam sebuah negeri yang bercorak muslim, kementerian ini merupakan suatu jalan tengah antara negara sekuler dan negara Islam.

Departemen Agama inilah yang secara intensif memperjuangkan politik pendidikan Islam di Indonesia. Orientasi usaha Departemen Agama dalam bidang pendidikan Islam bertumpu pada aspirasi umat Islam agar pendidikan agama diajarkan di sekolah-sekolah, di samping pada pengembangan pendidikan Islam dari pendidikan dasar, sampai pada tingkat pendidikan tinggi Islam.

Sejak masa itu, Departemen Agama mengelola sepenuhnya Pendidikan Islam. Namun, perhatian yang diberikan oleh Depertemen Agama dalam mengembangkan pendidikan Islam di masa awal kemerdekaan mendapat tantatangan dari kekutan nasionalis sekuler terutama di lembaga Badan Pekerja Nasional Indonesia Pusat (BP-KNIP) saat sidang-sidang dalam merumuskan Undang-Undang Pendidikan dan Pengajaran di Sekolah tahun 1949-1950. Pemerintah belum memosisikan pendidikan Islam terintegrasi ke dalam sistem pendidikan nasional. Salah satu

${ }^{5}$ Ira M. Lapidus, Sejarah Sosial Umat Islam, bagian ketiga, (Jakarta: RajaGrafindo Persada, 1999), h. 340. Lihat pula Musyrifah Sunanto, Sejarah Peradaban ..., h. 61. 
penyebabnya adalah selain masih kuatnya pengaruh zaman penjajahan Hindia Belanda dan Jepang di bidang pendidikan yang netral terhadap agama, ${ }^{6}$ juga masih kuatnya pengaruh kelompok nasionalis sekuler dalam pengambilan kebijakan negara di bidang pendidikan.

Sikap pemerintah yang demikian tidak terpisahkan dari kondisi politik negara yang belum stabil dengan berbagai kepentingan yang memengaruhinya. Secara politik, pada masa pemerintah Presiden Soekarno terjadi tarik-menarik antarkepentingan dan kekuatan kelompok nasionalis, kelompok agamis, dan kelompok nasionalis sekuler atau komunis dalam merumuskan berbagai kebijakan yang memberi arah ke mana negara dan bangsa ini dibawa. Hal tersebut ternyata sangat menguras waktu dan kurang memberi peluang bagi pemerintah untuk memperbaiki kondisi pendidikan Islam. ${ }^{7}$

Tiga kekuatan ideologis ini sering kali berbenturan dan saling mangalahkan. Presiden Soekarno adalah tokoh yang menganut ideologi nasionalis yang berbasis keindonesiaan dan kultural. Dalam posisinya itu, ia terkadang dekat dengan

${ }^{6}$ Besarnya pengaruh tersebut dapat dilihat pada praktik penyelenggaraan pendidikan Islam yang masih sepenuhnya mengajarkan ilmuilmu agama, juga pada lembaga pendidikan umum belum mewajibkan pengajaran pendidikan agama kecuali dengan persetujuan orang tua murid atau dengan sikap sukarela. Keadaan ini sangat dipengaruhi oleh kebijakan Belanda yang bersikap "netral" terhadap agama seperti yang dinyatakan dalam pasal 179 ayat (2) Indiche Staatsregeling bahwa pengajaran umum adalah netral, yang artinya pengajaran diberikan dengan menghormati keyakinan agama masing-masing. Di sekolah menengah umum yang berbahasa Belanda seperti Mulo (Meer hidgebreid Lager Onderwijst) dan AMS (Algemene Midddlebare School) pada tahun 1930 diajarkan pula pelajaran agama Islam bagi murid-murid yang berminat dan bersifat sukarela. Lihat Departemen Agama RI, Informasi Kelembagaan Agama Islam, “Dokumen”, h. 6.

${ }^{7}$ Abuddin Nata, Pendidikan Islam di Indonesia: Tantangan dan Peluang, Pidato Pengukuhan Guru Besar dalam Bidang Sejarah dan Filsafat Pendidikan Islam pada Fakultas Tarbiyah dan Pendidikan, h. 7. 
kelompok Islam dan terkadang dekat dengan kelompok sekulariskomunis. $^{8}$

Keadaan ini sangat berpengaruh dalam pengambilan keputusan-keputusan negara tentang pendidikan dan berimplikasi terhadap kondisi pendidikan Islam dalam sistem pendidikan nasional yang belum mendapat perhataian secara serius dalam kebijakan negara, sebagai bukti atas pernyataan tersebut pendidikan Islam belum terintegrasi dalam sistem pendidikan nasional seperti dirumuskan dalam rapat-rapat BP KNIP terhadap pendidikan Islam. Keputusan-keputusan BP KNIP yang memosisikan pendidikan Islam di luar sistem pendidikan nasional. Hal ini terlihat secara jelas dalam rumusan UndangUndang No. 4 tahun 1950 tentang Dasar-dasar Pendidikan dan Pengajaran di Sekolah.

Pngambilan kebijakan saat perumusan Undang-Undang Nomor 4 tahun 1950 tentang Pendidikan dan Pengajaran di Sekolah. Pada beberapa pasal yang berkaitan dengan pendidikan, tidak dimasukkan pendidikan Islam ke dalam sistem pendidikan nasional. Pendidikan Islam dalam bentuk Madrasah dan pesantren dianggap belum termasuk ke dalam sistem pendidikan nasional. ${ }^{9}$

Salah satu penyebabnya adalah karena kekalahan kelompok inteligensia Muslim dari kelompok nasionalis sekuler dalam perdebatan materi Undang-Undang Nomor 4 tahun 1950 sangat berpengaruh terhadap isi atau materi dalam undang-undang tersebut, sehingga substansi dari undang-undang ini tidak memihak kepada kepentingan dan kebutuhan umat Islam.

Dalam perkembangan selanjutnya terjadi pergantian sistem pemerintahan dari Presiden Soekarno ke Presiden Soeharto sejak

\footnotetext{
${ }^{8}$ Abuddin Nata, Manajemen Pendidikan Mengatasi Kelemahan Pendidikan di Indonesia, (Jakarta: Kencana, 2005), h. 14.

${ }^{9}$ Husni Rahim, Madrasah dalam Politik Pendidikan di Indonesia, (Cet. I; Jakarta: Logos Wacana Ilmu, 2005), h. 17.
} 
tahun 1966-1998. Peralihan kekuasaan ini berdasarkan sidang MPRS tahun 1968 yang menetapkan Supersemar, sehingga secara hukum ia menjadi sah. Sejak itu, Soeharto sebagai pemegang Supersemar ditetapkan menjadi Presiden RI yang kedua. Kehadiran Orde Baru ini membawa semangat untuk melakukan "koreksi total" yang dianggap menyimpang dari dasar negara yang pernah terjadi di masa pemerintah Presiden Soekarno.

Di bidang pendidikan di masa Pemerintah Orde Baru bertujuan untuk menekankan pada "Kualitas manusia Indonesia yang beriman dan bertakwa kepada Tuhan Yang Maha Esa, berkepribadian, cerdas, memiliki ilmu pengetahuan dan teknologi, memiliki keterampilan, mempertebal semangat kebangsaan dan cinta tanah air serta bertanggung jawab dalam pembangunan bangsa." Namun, dalam kenyataannya tujuan pendidikan yang telah dirumuskan, ditetapkan dan diamanatkan oleh MPRS dan MPR tampaknya belum mewujud di masa Orde Baru. Penyebabnya adalah selain dipengaruhi oleh faktor intern, juga dipengaruhi oleh faktor ekstern.

Faktor intern adalah tidak diikuti oleh sistem pendidikan yang kuat dan tidak didukung oleh manajemen yang baik sehingga pendidikan kurang berjalan secara efektif. Dalam praktiknya, kebijakan pemerintah Orde Baru menerapkan sistem yang sentralistik sehingga terjadi polarisasi yang seragam (uniformitas). Polarisasi yang sentralistik berdasarkan UndangUndang Nomor 5 tahun 1975 tentang Pemerintahan Daerah telah berimplikasi terhadap penyelenggaraan pemerintahan. Penyelenggaraan pemerintahan segalanya ditentukan oleh Pemerintah Pusat. Sistem ini berimplikasi terhadap pemerintah yang ada di daerah. Dapat dikatakan bahwa pemerintah daerah sangat lemah dalam prakarsa dan kreativitas untuk menyelesaikan barbagai masalah dan tantangan yang dihadapinya. 
Keleluasaan untuk menetapkan prioritas kebijakan yang merupakan syarat penting lahirnya prakarsa dan kreativitas tidak tersedia. Semua keputusan penting hanya bisa diambil oleh pemerintah pusat. Akibatnya, selalu terjadi kelambanan dalam merespons dinamika dan permasalahan yan terjadi di daerah. Dalam keadaan seperti ini, proses pembuatan kebijakan pastilah masyarakat menjadi sangat lemah. Keadaan tersebut sangat berpengaruh terhadap penyelenggaraan pembangunan termasuk pembangunan di bidang pendidikan dan sumber daya manusia Indonesia. Pendidikan seakan-akan dianggap hanya milik pemerintah bukan milik masyarakat.

Faktor ekstern adalah adanya kebijakan Pemerintah Orde Baru yang menekankan pemeliharaan keamanan, khususnya di masa-masa awal pemerintahannya, kondisi negara belum stabil baik dari aspek sosial politik, keamanan, dan ekonomi. Keadaan ini menjadikan kebijakan Soeharto menggunakan pendekatan keamanan tanpa kompromi terhadap sisa-sisa kekuatan komunis dan kekuatan pro-Soekarno sampai ke akar-akarnya dan meredam kekuatan demokratis yang mengganggu stabilitas pemerintahannya. ${ }^{10}$ Pendekatan keamanan yang diterapkan oleh Soeharto merupakan cikal-bakal lahirnya sistem kepemimpinan yang otoriter dan represif.

Dalam kaitan ini, Soedijarto mengemukakan pandangannya bahwa praktik politik Pemeritah Orde Baru selama 32 tahun

\footnotetext{
${ }^{10}$ Pendekatan stabilitas keamanan dilakukan oleh Soeharto yang memegang kekuasaan sebagai Presiden RI ke-2 diawali oleh sebuah pergerakan komunis yang dikenal dengan G.30 S/PKI. Begitu terjadi pemberontakan PKI tanggal 30 September 1965 yang dirasakan sangat kejam dan sadis membunuh para pemimpin teras Angkatan Darat, banyak pihak mulai sadar, betapa berbahayanya komunis jika keberadaannya dibiarkan, apalagi jika memberinya kesempatan untuk berpartisipasi di pemerintahan. Dengan terjadinya pengkhianatan PKI, segenap masyarakat bangkit dengan generasi barunya yang bersatu dengan ABRI, dalam melakukan penumpasan para PKI dan pendukungnya. Lihat, Hartono Marjono, Politik Indonesia (1996-2003), (Cet. II; Jakarta: Gema Insani Press, 1997), h. 25.
} 
berkuasa tersebut berimplikasi terhadap pendidikan nasional. Kebijakan politik tersebut sangat memengaruhi arah sistem pendidikan nasional yang dibangun dan dikembangkan Pemerintah Orde Baru. Pendidikan yang dikembangkan senantiasa disertai perubahan dan perkembangan yang ada di lingkungannya terutama yang terkait dengan aspek politik, ekonomi dan stabilitas keamanan. Ketiga aspek tersebut saling terkait dan saling memengaruhi.

Asumsi ini cukup beralasan karena didasarkan pada sebuah teori bahwa pendidikan dan bidang-bidang kehidupan lain yang terjadi di luar sistem pendidikan saling memengaruhi. Upaya memperjelas kaitan antara pendidikan dan bidang-bidang kehidupan di luar sistem pendidikan dimaksudkan agar tampak keterkaitan fungsionalnya dengan sistem pendidikan. Faktorfaktor tersebut meliputi kependudukan, politik, ekonomi, ketenagakerjaan, dan sosial-budaya. ${ }^{11}$

Abuddin Nata mengemukakan bahwa teori ini merupakan bukti bahwa politik pendidikan Pemerintah Orde Baru tidak jauh berbeda dengan kebijakan politiknya. Apabila kebijakan di bidang politik ini sangat melemahkan umat Islam, maka politik pendidikan yang ditempuh juga sama. Dengan demikian, terlihat bahwa kebijakan politik suatu negara akan sangat memengaruhi politik pendidikannya. ${ }^{12}$

Berdasarkan teori tersebut, Pemerintah Orde Baru dalam mengambil kebijakan di bidang pendidikan menyesuaikan dengan aspek keamanan dan ekonomi yang menjadi fokus penyelenggaraan program pemerintahannya. Praktik penyelenggaraan pemerintahan dengan pendekatan keamanan, pada gilirannya mendorong untuk bertindak represif dan otoriter.

\footnotetext{
${ }^{11}$ Ace Suryadi dan H.A.R. Tilaar, Analisis Kebijakan Pendidikan: Suatu Pengantar, (Bandung: Remaja Rosda Karya Tilaar, 1994), Cet. II, h. 3.

${ }^{12}$ Abuddin Nata, Manajemen Pendidikan ..., h. 20-21.
} 
Praktik pendidikan seperti ini tidak menghiraukan masalahmasalah fundamental, seperti partisipasi masyarakat dalam proses pendidikan anak bangsa. Pendidikan dibatasi pada pendidikan formal, sehingga masyarakat diasingkan dari proses pendidikan. Oleh karena itu, proses pendidikan menjadi bagian dari struktur kekuasaan yang ada. Tidak mengherankan apabila menajemen pendidikan dalam hal ini telah menjadi bagian dari manajemen kekuasaan. Hal tersebut lebih-lebih lagi diperparah oleh semakin terasingnya pendidikan formal dari kebutuhan masyarakat yang riil yang pada nantinya pendidikan berada dalam kondisi tanpa arah. ${ }^{13}$

Akibat kebijakan pendidikan yang demikian itu, pendidikan nasional di masa Pemerintah Orde Baru telah melahirkan manusia-manusia yang terasing baik bagi dirinya maupun bagi masyarakat. Tidak mengherankan apabila terdapat suatu jurang pemisah antara kebutuhan tenaga kerja dan lulusan sistem persekolahan. Yang dikejar adalah ijazah sampai kepada proses jual beli ijazah. "The diploma diseases" telah melanda sistem pendidikan di Indonesia sebagai salah satu hasil dari pedagogis tanpa arah. Demikian pula pengangguran sarjana semakin lama semakin banyak sehingga prestasi pendidikan menjadi misinvestasi yang bukan hanya merugikan individu, melainkan juga merugikan masyarakat bangsa Indonesia. ${ }^{14}$

Dalam kondisi seperti itu, berlakulah sistem pendidikan yang menghasilkan output pendidikan nasional yang tidak terkontrol atau yang merasa puas dengan diri sendiri. Terjadilah rasa puas terhadap hasil pendidikan nasional yang sebenarnya tidak terkontrol. Sikap angkuh terhadap pekerjaan sendiri karena tidak ada bahan perbandingan telah menyebabkan kemerosotan

${ }^{13}$ H.A.R. Tilaar, Pertanggungjawaban Manajemen Pendidikan dalam Menghidupi Pedagogik di Indonesia, (Makalah) dalam Konferensi Nasional Manajemen Pendidikan, (Jakarta: Hotel Indonesia, tanggal 8-10 Agustus 2002), h. 15.

${ }^{14}$ Ibid., h. 3. 
mutu pendidikan karena tujuannya hanya diorientasikan untuk memuaskan rasa sukses penguasa. ${ }^{15}$

Sekolah seolah menjadi tidak berdaya menghadapi kenyataan ini. Sejumlah masalah berat menghadang seperti kurikulum yang overload, fasilitas yang tidak memadai, serta kesejahteraan guru dan tenaga kependidikan yang rendah, sehingga sekolah seolah-olah kehilangan relevansinya sebagai pembentuk karakter. Sekolah, sebagai konsekuensinya, lebih merupakan sekadar tempat bagai transfer of knowledge daripada character building, tempat pengajaran daripada pendidikan. ${ }^{16}$

Oleh karena itu, di masa Pemerintah Orde Baru, pencapaian pendidikan nasional masih jauh dari harapan, apalagi untuk mampu bersaing secara kompetitif dengan perkembangan pendidikan pada tingkat global. Baik secara kuantitatif maupun kualitatif, pendidikan nasional bukan hanya belum berhasil meningkatkan kecerdasan dan keterampilan peserta didik, melainkan gagal dalam membentuk karakter dan kepribadian (nation and character building). ${ }^{17}$

Dalam kaitan dengan pendidikan Islam, kebijakan politik pendidikan Islam era pemerintah Orde Baru khususnya di masa awal pemerintahnya belum memerhatikan pengembangan pendidikan Islam bahkan cenderung mengalihkan pembinaan pendidikan Islam oleh Depertemen Agama ke Depertemen Pendidikan dan Kebudayaan seperti tercermin pada sejumlah kebijakan yang tertuang dalam peraturan-peraturan dan perundang-undangan berkenaan dengan pendidikan Islam.

Pada tahun 1972 dan 1974, lahir kebijakan yang ditetapkan dalam Surat Keputusan Presiden Nomor 34 tahun 1972 tentang Tanggung Jawab Fungsional Pendidikan dan Latihan, kemudian

\footnotetext{
${ }^{15}$ Ibid., h. 15.

${ }^{16}$ Azyumardi Azra, Paradigma Baru Pendidikan Nasional, Rekonstruksi dan Demokratisasi, (Cet. I; Jakarta: Kompas, 2002), , h. 173.

${ }^{17}$ Ibid,
} 
diperkuat oleh Instruksi Presiden Nomor 15 tahun 1974 tentang Pelaksanaan Keputusan Presiden Nomor 34 tahun 1972.

Dalam Keppres 34 tahun 1972 disebutkan pada pasal 1 ayat (2) yaitu "Mengatur standarisasi lembaga pendidikan dan latihan yang meliputi isi dan kualitas palajaran guna disesuaikan dengan kebutuhan pembangunan." Dalam pasal 1 ayat (4) "Mengatur dan mengawasi izin pendirian sesuatu lembaga pendidikan dan latihan." Pada pasal 2 juga disebutkan bahwa "Menteri Pendidikan dan Kebudayaan bertugas dan bertanggung-jawab atas pembinaan pendidikan dan latihan secara menyeluruh, baik yang diselenggarakan oleh pemerintah maupun swasta." ${ }^{18}$

Kebijakan pemerintah dalam Keppres Nomor 34 tahun 1972 tersebut merupakan salah satu bentuk hegemoni pemerintah di bidang pendidikan, baik dari sisi pengaturan standarisasi kualitas pendidikan untuk kebutuhan pembangunan yang dikehendaki oleh pemerintah, maupun pengaturan dan pengawasan tentang pendirian lembaga pendidikan negeri dan swasta. Bahkan, dengan kebijakan ini pemerintah berkeinginan untuk menjadikan pendidikan satu atap dalam pengelolaan Departemen Pendidikan dan Kebudayaan. Atas dasar itu, dapat dikatakan bahwa kebijakan bidang pendidikan tampaknya menjadi kewenangan otoritatif Pemerintah Orde Baru.

Demikian pula halnya dalam Inpres Nomor 15 tahun 1974, pasal 3 dikemukakan bahwa "Tugas dan kewajiban Menteri Pendidikan dan Kebudayaan sebagai pembantu Presiden di bidang pendidikan meliputi tanggung jawab fungsional pembinaan pendidikan dan latihan." Dalam bab III tentang pelaksanaan pembinaan dan latihan pasal 7 ayat (1) disebutkan bahwa

${ }^{18}$ Lihat Keputusan Presiden Republik Indonesia Nomor 34 tahun 1972 tentang Tanggung Jawab Fungsional Pendidikan dan Latihan, "Dokumen" Kantor Sekretariat Negara RI, h. 1-2. 
"Menteri Pendidikan dan Kebudayaan menetapkan kebijaksanaan pembinaan pendidikan dan latihan secara menyeluruh."19

Hal ini membuktikan bahwa masyarakat belum dilibatkan dalam penyelenggaraan pendidikan, karena pemerintah melalui Departemen Pendidikan dan Kebudayaan diberikan tanggung jawab dan kewenangan sepenuhnya untuk mengawasi, menetapkan kebijakan di bidang pendidikan dan latihan sebagai bentuk kontrol negara terhadap pendidikan. Kebijakan ini berimplikasi bagi pendidikan Islam yang diselenggarakan oleh Departemen Agama, karena adanya keinginan pemerintah untuk mengalihkan penyelenggaraan pendidikan Islam dari Departemen Agama ke Departemen Pendidikan Nasional. Keinginan pemerintah tersebut sebagai bentuk politisasi dalam mengatur dan mengontrol pendidikan.

Substansi Surat Keputusan Presiden dan Instruksi Presiden tersebut dianggap melemahkan dan mengasingkan lembaga pendidikan Islam dari sistem pendidikan nasional. Bahkan, sebagian umat Islam memandang Keppres dan Inpres sebagai manuver untuk mengabaikan peran dan manfaat lembaga pendidikan Islam yang sejak zaman penjajahan telah diselenggarakan oleh umat Islam. Situasi ini menandai ketegangan yang cukup keras dalam konteks pendidikan nasional. ${ }^{20}$

Tidak diketahui secara pasti hal yang melatari lahirnya Keppres tahun 1972 dan Inpres tahun 1974. Namun, dapat diduga bahwa salah satu penyebabnya adalah karena pada masa itu, yaitu sekitar tahun 1970-an, hubungan antara umat Islam dan Pemerintah Orde Baru kurang harmonis. Fenomena tersebut turut memengaruhi kebijakan-kebijakan pemeritah yang tidak

\footnotetext{
${ }^{19}$ Lihat Instruksi Presiden Republik Indonesia Nomor 15 tahun 1974 tentang Pelaksanaan Keputusan Presiden Nomor 34 tahun 1972, "Dokumen" Kantor Sekretariat Negara RI, h. 3-4.

${ }^{20}$ Husni Rahim, Madrasah ..., h. 18.
} 
berpihak kepada kepentingan dan kebutuhan umat Islam terutama terjadi di masa-masa awal pemerintahan Orde Baru.

Pada masa-masa awal pemerintahannya, hampir dapat dipastikan tidak ditemukannya kebijakan negara dalam bentuk peraturan pemerintah atau perundang-undangan yang aspiratif terhadap kepentingan dan kebutuhan umat Islam. Salah satu faktor yang memengaruhi hal tersebut adalah kekuasaan negara di dominasi oleh Angkatan Bersenjat Republik Indonesia (ABRI) yang berpandangan nasionalis sekuler dan selalu merasa curiga terhadap umat Islam.

Dalam hubungan ini, Bahtiar Effendy mengemukakan bahwa hubungan politik yang tidak harmonis itu berdampak luas. Puncaknya, akses para aktivis politik Islam ke koridor kekuasaan menyusut drastis dan posisi politik mereka merosot, terutama sepanjang 16 tahun pertama Pemerintahan Orde Baru. ${ }^{21}$ Islam politik dituduh sebagai ekstrem kanan karena dituduh mendirikan negara Islam dan anti Pancasila. Aktivitas Islam Politik dicurigai sehingga di masa-masa awal Pemerintah Orde Baru sampai pertengahan tahun 1970-an, sehingga pemerintah melakukan usaha politik untuk melemahkan posisi umat Islam. ${ }^{22}$ Mitos politik tentang pembangkangan Islam sangat dalam terpatri dalam kesadaran sejarah bangsa Indonesia. Kenyataan ini menyebabkan pengambilan kebijakan Orde Baru bersikap sangat kritis terhadap "Islam Politik". ${ }^{23}$ Keadaan ini jelas mempersulit umat Islam pada umumnya dalam upaya meningkatkan dan memajukan pendidikan Islam. ${ }^{24}$

Kenyataan seperti ini ingin diatas oleh generai baru Islam yang berpandangan modernis, substantif, kultural dan memiliki

${ }^{21}$ Bahtiar Effendy, Islam dan Negara Transformasi Pemikiran dan Politik Islam di Indonesia, (Cet. I; Jakarta: Paramadina, 1998), h. 270.

${ }^{22}$ Kuntowijoyo Identitas Politik Islam, (Cet. I; Bandung: Mizan dan Majalah Ummat, 1997), h. 189-199.

${ }^{23}$ Ibid., h. 199.

${ }^{24}$ Abuddin Nata, Pendidikan Islam..., h. 38. 
landasan teologis inklusif, menjadikan pandangan pemerintah berubah, dan mengokomodir kepentingan politik Islam di bidang pendidikan. Hal ini tercermin pada sikap akomodatif pemerintah terhadap umat Islam berimplikasi terhadap lahirnya kebijakan negara yang berkenaan dengan kebutuhan dan kepentingan umat Islam terutama yang berkenaan dengan kebijakan peningkatan dan pengembangan pendidikan Islam.

Sebagai bukti negara bersikap lunak tarhadap umat Islam adalah disahkannya sejumlah peraturan perundang-undangan dalam lembaran negara, seperti Surat Keputusan Bersama Tiga Menteri yang dikenal SKB Tiga Menteri, Menteri Pendidikan dan Kebudayaan RI, Menteri Agama RI, dan Menteri Dalam Negeri RI tanggal 24 Maret 1975 tentang Peningkatan Mutu Pendidikan pada Madrasah. Demikian pula ditetapkannya Undang-Undang Nomor 2 Tahun 1989 tentang Sistem Pendidikan Nasional, Peraturan Pemerintah Nomor 28 Tahun 1990 tentang Pendidikan Dasar, dan Peraturan Pemerintah Nomor 29 Tahun 1990 tentang Pendidikan Menengah. Lahirnya kebijakan negara tentang sistem pendidikan nasional tersebut menjadikan pendidikan Islam mengalami perubahan yang signifikan dalam melakukan pembaruan terhadap sistem pendidikanya yang berimplikasi pada pendidikan Islam terintegrasi secara kuat dalam sistem pendidikan nasional.

Dalam perkembangan pendidikan Islam terutama pasca pemerintahan Orde Baru sejak tahun 1998 sampai saat ini yang dikenal sebagai sistem pemerintahan Era Reformasi. Pada masa ini merupakan era baru dalam sistem pemerintahan Republik Indonesia sebagai koreksi terhadap sistem pemerintahan yang dibangun oleh pemerintah Orde Baru. ${ }^{25}$

${ }^{25}$ Lihat www.wikipedia.com (Diakses tanggal 7 April 2008). Lihat pula H.A. Malik Fadjar, et.al, Tim Nasional Reformasi Menuju Masyarakat Madani Kelompok Pendidikan dan Penembangan SDM, Flatform Reformasi Pendidikan 
Gerakan reformasi yang dimotori oleh mahasiswa tahun 1998, pada prinsipnya, mengandung empat tuntutan yang hendak diwujudkan, yaitu: 1) demokrasi; 2) kebebasan berpendapat dan berbeda pendapat; 3) keterbukaan; dan 4) otonomi. ${ }^{26}$ Keempat prinsip tersebut merupakan reaktualisasi dari nilai-nilai budaya Indonesia sebagai cita-cita Proklamasi Kemerdekaan 1945.

Sebagai respons atas keempat tuntutan reformasi tersebut, disusunlah kebijakan pemerintah yang termuat dalam UndangUndang Otonomi Daerah Nomor 22 tahun 1999 tentang Pemerintahan Daerah dan Undang-Undang Nomor 25 tentang Perimbangan Keuangan antara Pusat dan Daerah. Selanjutnya, ia direvisi menjadi Undang-Undang Nomor 32 tahun 2004 tentang Pemerintahan Daerah dan Undang-Undang Nomor 33 tahun 2004 tentang Perimbangan Keuangan antara Pemerintah Pusat dan Daerah. ${ }^{27}$

Undang-Undang tentang Otonomi Daerah tersebut telah mendelegasikan bidang pendidikan sebagai salah satu sistem pemerintahan daerah yang dikenal dengan desentralisasi pendidikan. Desentralisasi pendidikan ini merupakan bentuk penyerahan wewenang pemerintah pusat kepada daerah untuk menyelenggarakan pendidikan yang bertujuan agar pengelolaan pendidikan menjadi kewenangan daerah sehingga pengembangan, perencanaan, pelaksanaan, dan evaluasinya diharapkan lebih cepat, tepat, efisien, dan efektif khususnya untuk pemenuhan kebutuhan masyarakat di daerah dalam bidang pendidikan.

Dalam praktiknya Pemerintah Era Reformasi telah melakukan perubahan yang signifikan di bidang pendidikan

dan Pengembangan Sumber Daya Manusia, (Jakarta: Direktorat Jenderal Pembinaan Kelembagaan Agama Islam Departemen Agama RI, 1999), h. xviii.

${ }^{26}$ Ibid., h. 16.

${ }^{27}$ Lihat Undang-Undang Otonomi Daerah edisi terbaru, (Cet. I; Yogyakarta: Pustaka Pelajar, 2005), h. 4. 
dengan mengemban misi baru reformasi pendidikan dan sumber daya manusia yang bertumpu pada pembangunan bidang pendidikan nasional yang aspiratif, demokratis, dan partisipatif.

Sejalan dengan hal itu, terdapat empat isu kebijakan penyelenggaraan pendidikan nasional yang perlu direkonstruksi dalam rangka otonomi daerah, yaitu: 1) berkaitan dengan peningkatan mutu pendidikan; 2) efisiensi pengelolaan pendidikan; serta 3) relevansi pendidikan; dan 4) pemerataan pelayanan pendidikan. ${ }^{28}$ Tujuan dari perubahan sistem pendidikan nasional di Era Reformasi dalam rangka untuk peningkatan mutu pendidikan dan pelayanan pendidikan sesuai dengan kebutuhan dan dinamika yang berkembang dalam kehidupan masyarakat.

Untuk mewujudkan keinginan itu, dirumuskan UndangUndang Nomor 20 tahun 2003 tentang Sistem Pendidikan Nasional. Kebijakan ini bertujuan "Terwujudnya tatanan kehidupan masyarakat dan bangsa Indonesia yang bermutu sesuai dengan amanat Proklamasi Kemerdekaan 1945, bertekad untuk mewujudkan masyarakat madani Indonesia sebagai suatu masyarakat Pancasilais yang beriman dan bartakwa, memiliki cita-cita dan harapan masa depan, demokratis dan beradab, menjujung tinggi hak-hak asasi manusia, berakhlak mulia, tertib dan sadar hukum, koorporatif dan kompetitif, serta memiliki kesadaran dan solidaritas antargenerasi dan antarbangsa, maju dan mandiri, cakap dan cerdas, kreatif dan bertanggung jawab, serta berwawasan budaya. ${ }^{29}$

Dalam konteks ini, Departemen Agama sebagai penyelenggara pemerintahan di bidang pendidikan Islam telah

\footnotetext{
${ }^{28}$ Indra Jati Sidi, Kebijakan Penyelenggaraan Otonomi Daerah Bidang Pendidikan, (Makalah) (Bandung: PPS UPI, 2000). Lihat pula E. Mulyasa, Manajemen Berbasis Sekolah, Konsep Strategi dan Aplikasi, (Cet. III; Bandung: Remaja Rosda Karya, 2003), h. 6.

${ }^{29}$ H.A. Malik Fadjar, et. al. Platform ..., h. xv.
} 
merespons arah kebijakan pembangunan bangsa Indonesia di Era Reformasi. Kebijakan ini dikemukakan oleh Husni Rahim selaku Direktur Jenderal Kelembagaan Agama Islam dalam Rakor dengan Komisi IV DPR RI tanggal 26 Juni 2001. Dalam rakor tersebut dikemukakan:

"Pendidikan agama diharapkan dapat menjadi sarana bagi pengembangan pribadi, watak dan akhlak mulia peserta didik, serta pada pembentukan sikap dan perilaku berakhlak. Pengembangan pribadi, watak, dan akhlak mulia, selain dilakukan oleh lembaga pendidikan formal, juga oleh keluarga, lembaga sosial keagamaan, dan lembaga pendidikan tradisional keagamaan serta tempat-tempat ibadah. Pendidikan agama sangat strategis sebagai upaya peningkatan sumber daya manusia dan sangat besar peranannya dalam mewujudkan manusia yang berkualitas, karena pada hakikatnya manusia yang berkualitas, yaitu manusia beriman dan bertakwa, hanya terwujud melalui penghayatan dan pengamalan ajaran-ajaran agamanya." ${ }^{30}$

Penghayatan dan pengamalan ajaran agama yang dilandasi oleh iman dan takwa kepada Allah SWT, dengan memfungsingkan segala potensi yang dimiliki seperti akal, hati, dan sarana pengetahuan lainnya akan dapat menghantarkan manusia pada kebenaran yang hakiki, yaitu pada tingkat kesucian batin menuju hakikat kebenaran yang sesungguhnya. Dalam Al-Qur'an disebutkan $^{31}$

Ayat tersebut dapat dijadikan dalil dalam merumuskan arah dan tujuan yang hendak dicapai dalam pendidikan nasional yang diharapkan mampu menghantarkan peserta didik menjadi manusia yang beriman dan bertakwa secara konsisten sesuai

\footnotetext{
${ }^{30}$ Husni Rahim, Kebijakan Direktur Jenderal Kelembagaan Agama Islam di Bidang Pendidikan Agama dan Keagamaan Islam, (Dokumen Departemen Agama RI, 2001), h. 3.

${ }^{31}$ Ayat ini menggabarkan tentang manusia sebagai makhluk yang diciptakan menurut fitrah Allah. "Maka hadapkanlah wajahmu dengan lurus kepada agama (Allah); (tetaplah atas) fitrah Allah yang telah menciptakan manusia menurut fitrah itu. Tidak ada perubahan pada fitrah Allah. (Itulah) agama yang lurus; tetapi kebanyakan manusia tidak mengetahui." (QS. al-Rûm [30]: 30)
} 
dengan petunjuk ajaran agamanya. ${ }^{32}$ Lembaga pendidikan Islam yang fungsi utamanya memberikan pengajaran agama dan umum kepada peserta didik idealnya dapat memfungsikan dan mengoptimalkan seluruh potensi pendidikan yang dimiliki oleh peserta didik sekaligus dapat mengaktualisasikan visi dan misi pendidikan nasional.

Rumusan visi dan misi pendidikan nasional tersebut ditetapkan dalam Undang-Undang Sisdiknas No. 20 tahun 2003, Peraturan Pemerintah No. 19 tahun 2005 tentang Standar Nasional Pendidikan dan Peraturan Menteri Pendidikan Nasional No. 22 tahun 2006 tentang Standar Isi untuk Satuan Pendidikan Dasar dan Menengah.

Kebijakan di bidang Pendidikan nasional tersebut diharapkan mampu menjamin pemerataan kesempatan pendidikan, peningkatan mutu, dan relevansi serta efisiensi manajemen pendidikan. Peningkatan mutu pendidikan diarahkan untuk meningkatkan kualitas manusia Indonesia seutuhnya melalui olah hati, olah pikir, olah rasa, dan olah raga agar memiliki daya saing menghadapi tantangan global. Peningkatan relevansi pendidikan dimaksudkan untuk menghasilkan lulusan yang sesuai dengan tuntutan kebutuhan berbasis potensi sumber

\footnotetext{
${ }^{32}$ Abdul Fatah Jalil menafsirkan ayat ini bahwa manusia itu pada dasarnya dilahirkan dalam keadaan menuju jalan yang baik (fitrah) dan manusia dibekali dengan akal, hati, dan alat-alat pengetahuan yang mampu membantu memperoleh hal-hal yang sehat tanpa kecenderungan kepada hawa nafsu dan akan sampai pada tahap hakikat yang sebenarnya. 'Abdul Fattāh Jalīl, Min Ușūl al-Tarbawiyyah fĩ al-Islām (Kairo: t.p., 1997), h. 51. Imam Al-Ghazâlî menafsirkan ayat ini dengan mengemukakan bahwa bekerjanya akal, hati, dan alat-alat pendidikan itu tentunya masih dalam pengertian fitrah yang sampai pada hakikat. Untuk itu, pencapaian hakikat kebenaran hanya bisa ditempuh melalui proses bimbingan yang diberikan seseorang kepada orang lain, agar ia dapat berkembang secara maksimal kepada tujuan yang ingin dicapai. Istilah ta'îm dalam pandangan Imam Al-Ghazali adalah pengetahuan yang datang dari Allah SWT melalui ilmu al-mukāsyafah, yaitu ilmu yang langsung diperoleh dari Allah SWT. Lihat Al-Ghazālī, Ihyyā 'Ulūm al-Dīn, Jilid I, (Beirut: Dār al-Fikr, t.th.), h. 3.
} 
daya alam Indonesia. Peningkatan efisiensi manajemen pendidikan dilakukan melalui penerapan manajemen berbasis sekolah dan pembaruan pengelolaan pendidikan secara terencana, terarah, dan berkesinambungan. ${ }^{33}$

Dalam konteks ini pendidikan Islam berperan aktif untuk mewujudkan visi dan misi pendidikan nasional tersebut dengan membangun paradigma baru dalam mengembangkan keilmuan Islam di lembaga pendidikan yaitu mengembangkan integrasi ilmu agama dan ilmu umum. Oleh karena itu pendidikan Islam senantiasa dapat mengembangkan ilmu pengetahuan dan teknologi yang dilandasi oleh nilai moral dan agama. Penguasaan ilmu pengetahuan dan teknologi dewasa ini menjadi keharusan untuk kemaslahatan dan kemajuan umat Islam di masa kini dan masa datang. Sebab, tanpa penguasaan ilmu pengetahuan dan teknologi yang dilandasi oleh semangat agama, dapat dipastikan bahwa umat Islam akan tertinggal dalam peradaban umat manusia di masa depan.

Oleh karena itu, lembaga pendidikan Islam senantiasa melakukan revitalisasi baik dari sisi kelembagaan maupun dari sisi keilmuannya. Revitalisasi lembaga pendidikan Islam dalam konteks ke depan (global) dapat dipahami dari upaya untuk menarik lembaga pendidikan Islam dalam mainstream yakni lebih berperan dalam pembangunan masyarakat. Untuk itu, lembaga pendidikan Islam dihadapkan pada tantangan untuk mengintegrasikan nilai-nilai ajaran agama dalam ilmu pengetahuan dan teknologi. Dengan kata lain, lembaga pendidikan harus memberi bekal berupa penguasaan ilmu pengetahuan dan teknologi kepada murid atau mahasiswa dan lulusan secara memadai (distinctive competence). ${ }^{34}$

\footnotetext{
${ }^{33}$ Peraturan Menteri Pendidikan Nasional Nomor 22 tahun 2006 tentang Standar Isi Pendidikan Dasar dan Menengah, h. 73.

${ }^{34}$ Husni Rahim, Madrasah dalam ..., h. 30.
} 
Tujuan dari itu adalah agar akses terbuka terhadap pendidikan tinggi dalam bidang ilmu pengetahuan dan teknologi dapat dimanfaatkan secara optimal oleh lulusan lembaga pendidikan ini yang pada akhirnya akan melahirkan ilmuwan yang komit dengan nilai agama (Islam) dalam mengkaji dan mengembangkan ilmu pengetahuan mendatang (pembangungan masyarakat ke depan). ${ }^{35}$

Apabila hal ini dapat dilakukan di lembaga pendidikan Islam, maka lembaga ini ke depan dapat dijadikan sebagai lembaga pendidikan alternatif bagi anak bangsa dalam merespons perubahan di era globalisasi. Oleh karena itu, respons negara terhadap kebutuhan umat Islam dengan memasukkan lembaga pendidikan Islam baik pada tingkat madrasah sampai pada tingkat pendidikan tinggi Islam sebagai pendidikan yang sama dengan sekolah umum dan pendidikan tinggi umum dalam sistem pendidikan nasional merupakan upaya pemerintah dalam memajukan pendidikan umat Islam di Indonesia.

\section{PENUTUP}

Dilihat dari perspektif politik pendidikan bahwa Pendidikan dapat memengaruhi politik dan politik dapat tersosialisasi melalui pendidikan. Hal ini dibuktikan dalam perubahan dan perkembangan pendidikan Islam dalam peta politik pendidikan Islam yang mengalami dinamika berdasarkan tingkat kepetingan para pemangku kepentingan dalam pengambilan kebijakan negara dalam sistem pendidikan nasional. Oleh karena umat Islam perlu memahami politik pendidikan agar Umat Islam di Indonesia terutama aktivis politik Islam dapat memperjuangkan kebutuhan dan kepentingan pendidikan Islam. Tujuan diperjuangkannya pendidikan Islam dalam sistem pendidikan nasioanal adalah untuk memiliki sisi persamaan dan setara antara pendidikan yang dikelola oleh Kementerian Pendidikan Nasional

\footnotetext{
${ }^{35}$ Ibid., h. 77.
} 
dengan pendidikan Islam yang dikelola oleh Kementerian Agama dalam sistem pendidikan nasional.

\section{DAFTAR PUSTAKA}

Azra, Azyumardi, Paradigma Baru Pendidikan Nasional, Rekonstruksi dan Demokratisasi, Cet. I; Jakarta: Kompas, 2002

Departemen Agama RI, Informasi Kelembagaan Agama Islam, "Dokumen",

Effendy, Bahtiar, Islam dan Negara: Transformasi Pemikiran dan Praktik Politik Islam di Indonesia, Cet. I; Jakarta: Paramadina, 1998.

Effendy, Bahtiar, Jalan Tengah Politik Islam, Cet. I; Jakarta: Ushul Press, 2005.

Fadjar, Malik, H.A. et.al, Tim Nasional Reformasi Menuju Masyarakat Madani Kelompok Pendidikan dan Penembangan SDM, Flatform Reformasi Pendidikan dan Pengembangan Sumber Daya Manusia, Jakarta: Direktorat Jenderal Pembinaan Kelembagaan Agama Islam Departemen Agama RI, 1999.

Jalīl, Abdul Fattāḥ , Min Ushūl al-Tarbawiyah fi al-Islām, Kairo: t.p., 1997

Jenkin, Thomas P., The Study of Political Theory, New York: Random House Inc., 1967.

Kuntowijoyo Identitas Politik Islam, Cet. I; Mizan dan Majalah Ummat, 1997.

M. Lapidus, Ira, Sejarah Sosial Umat Islam, bagian ketiga, Jakarta: RajaGrafindo Persada, 1999.

Mulyasa, E., Manajemen Berbasis Sekolah, Konsep Strategi dan Aplikasi, Cet. III; Bandung: Remaja Rosda Karya, 2003. 
Nata, Abuddin, Manajemen Pendidikan Mengatasi Kelemahan Pendidikan di Indonesia, Jakarta: Kencana, 2005.

Nata, Abuddin, Pendidikan Islam di Indonesia: Tantangan dan Peluang, Pidato Pengukuhan Guru Besar dalam Bidang Sejarah dan Filsafat Pendidikan Islam pada Fakultas Tarbiyah dan Keguruan Universitas Islam Negeri Syarif Hidayatullah Jakarta, 2004.

P. Jenkin, Thomas, The Study of Political Theory, New York: Random House Inc., 1967.

Peraturan Menteri Pendidikan Nasional Nomor 22 tahun 2006 tentang Standar Isi Pendidikan Dasar dan Menengah

Peraturan Pemerintah Republik Indonesia Nomor 39 tahun 1992 tentang Peran Serta Masyarakat dalam Pendidikan Nasional, “Dokumen"Kantor Sekretariat Negara RI

Rahim, Husni, Kebijakan Direktur Jenderal Kelembagaan Agama Islam di Bidang Pendidikan Agama dan Keagamaan Islam, (Dokumen Departemen Agama RI, 2001)

Rahim, Husni, Madrasah dalam Politik Pendidikan di Indonesia, Cet. I; Jakarta: Logos Wacana Ilmu, 2005.

Rasyid, Muhammad Riyaas, Otonomi Daerah Prakarsa Pemerintahan B.J. Habibie dalam Kementar dan Pendapat Detik-detik yang Menentukan Jalan Panjang Indonesia Menuju Demokrasi,

Sidi, Indra Jati, Kebijakan Penyelenggaraan Otonomi Daerah Bidang Pendidikan, (Makalah), Bandung: PPS UPI, 2000.

Sunanto, Musyrifah, Sejarah Peradaban Islam Indonesia, Cet. I; Jakarta: RajaGrafindo Persada, 2005

Syam, Firdaus, Amin Rais dan Yusril Izha Mahendra di Pentas Indonesia Modern, Cet. I; Jakarta: Khairul Bayan, 2003. 
Vol. 10, No. 1, Juni 2013: 177-202

H.A.R. Tilaar, Pertanggungjawaban Manajemen Pendidikan dalam Menghidupi Pedagogik di Indonesia, (Makalah) dalam Konferensi Nasional Manajemen Pendidikan, Jakarta: Hotel Indonesia, tanggal 8-10 Agustus 2002

Undang-Undang Otonomi Daerah edisi terbaru, Cet. I; Yogyakarta: Pustaka Pelajar, 2005. 